УДК 346.91:347.232 (477)

DOI https://doi.org/10.32844/2618-1258.2019.3-1.2

БУДУРОВА Г.М.

\title{
УМОВИ НАБУТТЯ ПРАВА ВЛАСНОСТІ СУБ'СКТАМИ ГОСПОДАРЮВАННЯ ЗА НАБУВАЛЬНОЮ ДАВНІСТЮ: СУЧАСНА ПРАКТИКА ГОСПОДАРСЬКИХ СУДІВ
}

Стаття присвячена дослідженню умов набуття права власності суб'єктами господарювання за набувальною давністю. Проведено аналіз законодавства та новітньої судової практики Касаційного господарського суду та Великої палати Верховного Суду із цього питання. Окрема увага приділена аналізу добросовісності та безтитульності володіння як умовам набуття права власності в разі первісного заволодіння майном та протягом строку давності володіння. Набувальна давність віднесена до первісних способів набуття права власності, за якими право власності набувається особою незалежно від волі первісного власника. Обгрунтовано, що набувальна давність передбачає знаходження в особи речі або іншого майна протягом досить тривалого періоду, протягом якого власник не заявляє вимог щодо іiї витребування, проте цілком може бути обізнаний про знаходження його майна в іншої особи, про що свідчить вимога про відкрите володіння. У статті проаналізовано перелік умов, вироблених судовою практикою, одночасне дотримання яких необхідне для набуття майна у власність за набувальною давністю. До них належать: наявність суб'єкта, здатного набути у власність певний об'єкт; законність об'єкта володіння; добросовісність заволодіння чужим майном; відкритість володіння; безперервність володіння; сплив установлених строків володіння; відсутність норми закону про обмеження або заборону набуття права власності за набувальною давністю. Обгрунтовано суперечливість необхідності одночасно встановлювати володіння чужим майном без будь-якої правової підстави (безтитульність) і те, що особа не знала і не могла знати про відсутність у неї підстав для набуття права власності (добросовісність у розумінні Великої палати Верховного Суду). Тому зроблено висновок, що незнання і неможливість особи знати про відсутність у неї підстав для набуття права власності не є загальною умовою набуття цією особою права власності за набувальною давністю. Крім того, доведено, що набуття права власності за набувальною давністю передбачає відсутність будь-якого конкретного правового титулу для знаходження майна у володільця протягом перебігу строку позовної давності.

Ключові слова: право власності, набувальна давність, добросовісний набувач, володілець, безперервність володіння.

The article is devoted to the study of conditions of acquiring of ownership rights by business entities under acquisitive prescription. The legislation and the latest jurisprudence of the Cassation economic court and the Grand Chamber of the Supreme Court have been analyzed. Particular consideration was given to the analysis of the good faith of ownership and a concept of possession in fact as a condition of acquiring of ownership rights on the initial seizure of property and during the period of limitation period of possession. Acquisition prescription refers to the original ways of acquiring property rights, where by ownership is acquired by a person regardless of the will of the original owner. It is justified that the acquisitive prescription presupposes the possession of a thing or other property by a person for a sufficiently long period during which the owner does not claims its with draw al, but may be aware of bearing of his property by an other person, as evidenced by the requirement of open ownership. The article analyzes the list of conditions produced by the jurisprudence, the simultaneous observance of which

(C) БУДУРОВА Г.М. - кандидат юридичних наук, доцент кафедри господарського права і процесу (Національний університет «Одеська юридична академія») 
is necessary for the acquiring of the property under the acquisitive prescription. These include: the presence of a person capable of acquiring a particular object; the legality of the object of ownership; bona fide seizure of another's property; open ownership; continuity of ownership; expiration of the established term of ownership; the absence of a law on the restriction or prohibition of the acquiring of ownership right under the acquisitive prescription. The contradiction of the need to simultaneously establish possession of another's property without any legal basis (in fact) and the fact that the person did not know and could not know about the lack of grounds for acquiring the ownership right (good faith in the conception of the Grand Chamber of the Supreme Court) is substantiated. Therefore, has been made a conclusion that ignorance and inability of a person to know about the lack of grounds for acquiring ownership rights is not a general condition for acquiring by that person of ownership under the acquisitive prescription. In addition, it has been proved that the acquiring of ownership right under the acquisitive prescription presupposes the absence of any specific legal title for bearing the property by the owner during the limitation period.

Key words: right of ownership, limitation period, bona fide purchaser, owner, continuity of ownership.

Вступ. Право власності є основним речовим правом, яке забезпечує суб’єктам господарювання можливість найбільш ефективного використання економічних та юридичних властивостей майнових об'єктів. Тому в сучасних умовах господарювання вкрай актуальними залишаються питання якісного правового регулювання питань набуття та захисту права власності.

Однією з підстав для набуття права власності суб'єктами господарювання є набувальна давність, яка допускає можливість визнання за особою права власності на майно за дотримання низки умов - відкритості, безперервності, добросовісності володіння тощо. Зміст деяких із них, попри лаконічність їх визначення в Цивільному кодексі України, не має спірного характеру, вони досить просто піддаються об'єктивному встановленню, тоді як для визначення суті деяких інших (добросовісності заволодіння, титульності/безтитульності володіння) такого обмеженого правового регулювання недостатньо. За таких обставин зростає необхідність дослідження актуальної судової практики, за допомогою якої уточнюються законодавчі приписи щодо набувальної давності.

Варто підкреслити, що в рішенні Європейського суду з прав людини у справі компанії «Джей. Ей. Пай (Оксфорд) Лтд. та Джей. Ей. Пай (Оксфорд) Ленд Лтд. проти Сполученого Королівства» закріплено необхідність існування ефективного механізму набувальної давності, оскільки інститут набувальної давності сприяє попередженню невизначеності і несправедливості, до яких призводить подача позовів із порушенням встановлених строків (для континентальної системи права), уникненню небезпеки того, що майно втратить ринкову вартість у результаті відсутності визначеності щодо того, хто несе тягар утримання майна, - володілець або власник, уникненню проблем, з якими може зіткнутися особа, яка сумлінно помилялася під час заволодіння майном і яка, можливо, заволодівши майном, вклала в нього свої кошти; а також може полегшити встановлення власника майна [1].

Питанню набуття права власності на майно за набувальною давністю присвячено низку наукових праць і досліджень. Зокрема, цією проблематикою цікавилися такі теоретики та практики, як: Я. Білий, І. Івашова, Т. Кравченко, М. Михайлів, О. Печений, К. Рибалко, І. СпасибоФатєєва й ін.

Водночас дослідження з питань набувальної давності, які б мали комплексний характер та визначали концептуальні засади набуття майна за набувальною давністю, нині відсутні. Зазначене зумовлює залежність суб'єктів господарювання від численних, часом суперечливих і мінливих судових рішень, що тлумачать і встановлюють зміст окремих умов, з дотриманням яких закон пов'язує набуття права власності за набувальною давністю.

Постановка завдання. Мета статті - дослідження новітньої судової практики господарських судів, якою сформульовано сукупність умов, дотримання та доведення яких дасть змогу суб' єктам господарювання захистити свої права та визнати в судовому порядку право власності на майно, а також краще зрозуміти порядок реалізації закріплених законодавчих положень.

Результати дослідження. Питанню визначення підстав для набуття права власності присвячені положення гл. 24 р. І Книги третьої Цивільного кодексу (далі - ЦК) України «Право власності та інші речові права». 
Відповідно до ч. 1 ст. 328 ЦК України, право власності набувається на підставах, що не заборонені законом, зокрема із правочинів [2]. Підставами для набуття права власності ЦК України називає певні юридичні факти і конкретні життєві обставини, у зв'язку з якими право власності виникає. Ці обставини розглядаються науковцями як «способи набуття права власності» і поділяються на первісні і похідні шляхом застосування критерію наявності волі особи.

Так, до первісних підстав відносять ті способи набуття права власності, за якими воно виникає на річ вперше або незалежно від волі попередніх власників (новостворене майно, переробка речі, привласнення загальнодоступних дарів природи тощо), а до похідних - підстави, за якими право власності на річ виникає за волею попереднього власника (правочини, спадкування тощо) [3, с. 325]. Набувальна давність віднесена до первісних способів набуття права власності, отже, право власності набувається особою незалежно від волі первісного власника.

За загальним правилом, встановленим ч. 1 ст. 344 ЦК України, особа, яка добросовісно заволоділа чужим майном і продовжує відкрито, безперервно володіти нерухомим майном протягом десяти років або рухомим майном протягом п'яти років, набуває право власності на це майно (набувальна давність), якщо інше не встановлено цим Кодексом. По суті, набувальна давність передбачає знаходження в особи речі або іншого майна протягом досить тривалого періоду, протягом якого власник не заявляє вимог щодо його витребування, проте цілком може бути обізнаний про знаходження його майна в іншої особи, про що свідчить вимога про відкрите володіння.

Перелік умов, дотримання яких є необхідним для набуття майна у власність за набувальною давністю, встановлюється за положеннями ч. 1 ст. 344 ЦК України. Т. Кравченко виділяє такі: добросовісність володіння, відкритість володіння майном, безперервність володіння майном, володіння протягом встановленого законом строку [4]. У судовій практиці набуття права власності за давністю володіння пов'язується із сукупністю більш широкого кола обставин, якот: наявність суб'єкта, здатного набути у власність певний об'єкт; законність об'єкта володіння; добросовісність заволодіння чужим майном; відкритість володіння; безперервність володіння; сплив установлених строків володіння; відсутність норми закону про обмеження або заборону набуття права власності за набувальною давністю [5].

Так, набувальна давність $є$ тією підставою, на якій будь-які учасники відносин у сфері господарювання, а не лише суб' єкти господарювання - фізичні-особи підприємці та юридичні особи - підприємства, установи, організації, можуть набувати майно у власність. На цій підставі може набувати майно також держава та територіальна громада через відсутність заборон і спеціальних вимог щодо набувача у ст. 344 ЦК України та зміст ст. 2 ЦК України, де згадані особи називаються серед учасників цивільних правовідносин. У зв'язку із цим не можна погодитись 3 О. Печеним, який виключає згаданих осіб із переліку суб'єктів набувальної давності, наголошуючи, що для них ЦК України передбачає інші підстави для набуття права власності (набуття права власності на безхазяйну річ (ст. 336 ЦК), бездоглядну домашню тварину (ст. 341 ЦК), скарб, що становить культурну цінність (ч. 4 ст. 343 ЦК), спадщину, визнану судом відумерлою (ч. 3 ст. 1277 ЦК)) [6, с. 19].

За загальним правилом, вимога щодо законності об'єкта володіння означає можливість набути у власність за набувальною давністю будь-який об'єкт, крім тих, що вилучені із цивільного обігу (ст. 178 ЦК України). Проте, за обгрунтованим твердженням Я. Білого, відповідна підстава не може бути застосована і щодо таких об'єктів, щодо яких не може бути встановлене право власності як абсолютне речове право (майнові права, результати інтелектуальної, творчої діяльності, інформація тощо) [7].

Вимога щодо відкритості володіння визнається судом дотриманою, якщо особа не приховувала факт знаходження майна в ії̈ володінні. Водночас вжиття звичайних заходів щодо забезпечення охорони майна не свідчить про приховування цього майна [8].

Володіння визнається безперервним, якщо воно не переривалось протягом усього строку набувальної давності. Згідно із ч. 3 ст. 344 ЦК України, втрата не зі своєї волі майна його володільцем не перериває набувальної давності в разі повернення майна протягом одного року або пред'явлення протягом цього строку позову про його витребування. Крім того, особа, яка заявляє про давність володіння, може приєднати до часу свого володіння весь час, протягом якого цим майном володіла особа, чиїм спадкоємцем (правонаступником) вона є (ч. 3 ст. 344 ЦК України). Зазначена обставина також не перериває строку набувальної давності. Уточнення щодо безперервності здійснено Верховним Судом у складі колегії суддів Касаційного господарського суду у справі № 920/999/16: «<...> не перериває набувальної давності здійснення володільцем фактичного розпорядження майном у вигляді передання його в тимчасове користування іншій особі» [9]. 
Найбільше дискусій і в науковій літературі, і на практиці викликає встановлення змісту такої умови, як добросовісність заволодіння чужим майном. Як видається, у разі застосування набувальної давності мають бути встановлені і розмежовані два моменти в питанні заволодіння чужим майном:

(1) добросовісність первісного заволодіння майном володільцем (яким чином воно, власне, опинилось у володінні особи-володільця);

(2) безтитульність володіння майном протягом строку набувальної давності.

М. Михайлів наголошує, що потреба в набувальній давності виникає з таких причин, як: втрата власником, який проволодів майном достатній проміжок часу, доказів, що майно належить йому на законних підставах, і в судовому порядку він не може довести своїх прав; у разі пропуску строку позовної давності без поважних причин на звернення щодо повернення задавненого майна тощо [10, с. 164]. Перший з описаних випадків вказує на правомірне титульне заволодіння власником майном, другий - утримання майна у володінні без правового титулу (через те, що власник пропустив строк на витребування майна у володільця, у якого воно опинилось поза волею власника).

На думку І. Спасибо-Фатєєвої, річ первісно може потрапити до володільця як на підставі договору, так і без такого. Тобто це може бути будь-яке заволодіння - захоплення речі, залишення речі, строк користування якого за договором закінчився, та ін. [11]. Отже, для первісного заволодіння майном можуть бути прийнятними як випадки титульного, так і випадки безтитульного заволодіння майном. Безтитульне володіння - це фактичне володіння, яке не спирається на будьяку правову підставу володіння чужим майном. Фактичне володіння майном характеризується наявністю суб'єктивного й об'єктивного критеріїв, тобто наявністю речі у фактичному володінні особи та за ставлення до неї, як до своєї [12, с. 43].

Важливим є питання, чи підходять для первісного заволодіння майном для випадку набувальної давності правочини і договори, за якими майно набувається у власність. На перший погляд, така підстава може видатись неприйнятною, оскільки в разі набуття за договором права власності на майно не може вестись мова про строковість такого права - право власності, як відомо, $є$ безстроковим (строковість вживається лише в контексті набуття правомочностей володіння і користування, що виникають на речовій чи зобов'язальній основі). Тому визнати допустимим використання договорів про набуття майна у власність як підстави для заволодіння майном можна лише за умови, що такі договори матимуть дефекти, які призводитимуть до спорів чи невизначеності в питанні, хто є власником такого майна. Водночас недоліки відповідних договорів можуть стосуватися відсутності доказів щодо підтвердження права власності на майно (втрата примірників договорів і актів приймання-передачі, документів про оплату, неналежним чином оформлені правовстановлюючі документи й ін.) або наявності підстав щодо визнання таких договорів недійсними (про які сторони не знали), що перешкоджатимуть виникненню в особи щодо такого майна права власності в разі його первісного заволодіння. Однак сам факт їх укладення буде достатнім для визнання переходу речі у володіння нового володільця правомірним. Якщо ж володілець знає або повинен знати про неправомірність заволодіння чужим майном (зокрема, і про підстави для визнання договору про його відчуження недійсним), то, незважаючи на будь-який строк безперервного володіння чужим майном, він не може його задавнити, оскільки відсутня безумовна умова набуття права власності - добросовісність заволодіння майном [9].

Верховний Суд у справі № 910/17274/17 зауважив, що «підставою для добросовісного заволодіння майном не може бути, зокрема, будь-який договір, що опосередковує передання майна особі у володіння (володіння та користування), проте не у власність. Володіння майном за договором, що опосередковує передання майна особі у володіння (володіння та користування), проте не у власність, виключає можливість набуття майна у власність за набувальною давністю, адже у цьому разі володілець володіє майном не як власник» [5]. Зазначене можна обгрунтувати тією обставиною, що правомочність володіння, що грунтується на зобов'язальному (договірному) праві, $\epsilon$ похідною від правомочності власника та строковою, про що завжди відомо володільцю.

3 наведеного можна зробити висновок, що первісне заволодіння майном повинно мати ознаки акту, спрямованого на отримання спірного майна у власність, отже, і підстави для його набуття мають бути такими, з якими закон пов'язує виникнення права власності, а обставини набуття не мають викликати сумнівів в особи у правомірності такого заволодіння.

Отже, умова добросовісного заволодіння майном за змістом ст. 344 ЦК України охоплює випадки первісного титульного або безтитульного заволодіння майном особою, яка в подальшому претендуватиме на його набуття у власність за набувальною давністю. Єдиний виняток із 
правила, що титульне заволодіння передбачає наявність договору про набуття майна у власність, міститься в ч. 3 ст. 344 ЦК України і пов'язується з первісним набуттям майна у володіння чи володіння і користування на підставі договору з його власником, який після закінчення строку договору не пред'явив вимоги про його повернення. У такому разі володілець набуває право власності за набувальною давністю на нерухоме майно через п’ятнадцять, а на рухоме - через п'ять років із часу спливу позовної давності. Наведені положення вимагають від володільця дочекатися закінчення строку титульного володіння та спливу строку давності, протягом якого власник може витребувати майно у володільця.

Складність у кваліфікації первісних підстав заволодіння чужим майном як таких, що $\epsilon$ прийнятними для застосування набувальної давності, пов'язується 3 необхідністю одночасного встановлення добросовісності в діях особи-володільця під час заволодіння майном.

Так, Велика палата Верховного Суду підкреслює, що «при вирішенні спорів має значення факт добросовісності заявника саме на момент отримання ним майна (заволодіння майном), тобто на той початковий момент, який включається в повний давнісний строк володіння майном, визначений законом. Володілець майна в момент його заволодіння не знає (i не повинен знати) про неправомірність заволодіння майном. Крім того, позивач як володілець майна повинен бути впевнений у тому, що на це майно не претендують інші особи, і він отримав це майно за таких обставин і з таких підстав, які є достатніми для отримання права власності на нього» [5].

На нашу думку, встановлення добросовісності в розумінні, запропонованому Великою палатою Верховного Суду, не може вважатися загальною умовою для набуття права власності за набувальною давністю $з$ таких підстав (подібна позиція висловлена в ухвалі Верховного Суду у складі колегії суддів Касаційного цивільного суду від 4 грудня 2018 р. у справі № 910/17274/17 [13]).

По-перше, вимога про одночасне встановлення незнання та неможливості володільця знати про відсутність у нього підстав для набуття права власності (добросовісність володіння) та безтитульність для набуття права власності за ст. 344 ЦК України суперечить правилам формальної логіки: як може особа говорити про незнання того, що вона не могла бути потенційним власником, якщо майно опинилось у неї без жодної чіткої правової підстави (інакше чим особа, обізнана із безтитульністю свого заволодіння чужим майном (відсутній договір, правочин, інша законна підстава), може обгрунтувати виникнення в неї права власності щодо цього майна)?

По-друге, протилежний висновок спростовується і приписами ч. 3 ст. 344 ЦК України, яка прямо закріплює випадок, коли володілець знає про закінчення строку титульного володіння, але річ не повертає. А зі спливом встановленого строку може набути на неї право власності, попри свою первісну обізнаність про те, що річ перейшла до нього від законного власника лише у строкове володіння та користування. Неповернення майна після спливу строку свідчить про недобросовісність володільця, проте положення закону надають йому можливість набути право власності на це майно, задавнивши його.

По-третє, наведене розуміння добросовісності істотно звужує можливості використання набувальної давності як підстави для набуття майна у власність: виходячи з аналізу підстав, наведених у гл. 24 ЦК України, за набувальною давністю можна набути право власності на майно, яке не має власника, або власник якого невідомий, або власник відмовився від права власності на належне йому нерухоме майно та майно, що придбане добросовісним набувачем і у витребуванні якого його власнику було відмовлено (див., наприклад, постанову Верховного Суду (далі - ВС) у складі колегії суддів Першої судової палати Касаційного цивільного суду від 1 серпня 2018 р. № 201/12550/16-ц).

Другий важливий момент, який має бути доведений для набуття права власності за набувальною давністю, стосується встановлення безтитульності володіння майном протягом строку набувальної давності, що означає відсутність будь-якої законної підстави володільцеві тримати річ у себе. Інакше перебування майна у володільця на певному правовому титулі приводить до виникнення правовідносин, що відповідають підставі (титулу) заволодіння таким майном, і врегульовуються вони відповідними (спеціальними) нормами права (наприклад, щодо безпідставного збагачення, договірних чи деліктних зобов'язань тощо), що заперечує застосування набувальної давності.

У цивілістиці наголошується, що набувальна давність поширюється на випадки фактичного, безтитульного володіння чужим майном. Наявність у володільця певного юридичного титулу, наприклад, договору найму, оренди, зберігання тощо виключає застосування набувальної давності [3, с. 565]. Справді, не може бути визнане прийнятним і перебування у володільця майна на певному зобов'язальному титулі протягом перебігу строку набувальної давності, що передбачає 
строкове чи безстрокове володіння і користування (без набуття права власності). Виходячи із принципу правової визначеності, володілець у такому разі чітко розуміє свої права й обов'язки, надані йому відповідним інститутом, - будь-то сервітут, емфітевзис, суперфіцій, оренда тощо.

Таке володіння, по суті, стає можливим лише з огляду на відсутність вимог із боку законного власника щодо його витребування, а також інших невласників, які не заволоділи цією річчю (майном) раніше за володільця. Для всіх перелічених осіб - і власника, і третіх осіб - володіння має бути відкритим, очевидним. Протягом цього періоду добросовісність володільця, як слушно зазначено Касаційним господарським судом ВС, проявляється в невчиненні особою перешкод власнику майна в реалізації ним свого права власності на майно протягом строку, визначеного у ст. 344 ЦК України [13].

Висновки. Встановлення чіткого змісту умов, із дотриманням яких закон пов'язує визнання права власності на майно за набувальною давністю, необхідне для ефективного захисту прав і законних інтересів суб'єктів господарювання та сприяє стабільності відносин у сфері господарювання. Сучасна практика Верховного Суду з господарських справ уточнює правила застосування інституту набувальної давності, закріплюючи підхід до обов'язкового встановлення добросовісності первісного заволодіння майном, що є суперечливим у випадку, якщо майно опинилось в особи без жодних правових підстав (титулів). Дотримання цієї умови як основної значно обмежить кількість випадків застосування набувальної давності, але навряд чи сприятиме зменшенню кількості спорів між суб'єктами господарювання.

\section{Список використаних джерел:}

1.Pye J.A. (Oxford) Land Ltd v. the United Kingdom [GC], № 44302/02, ECHR 2007-III (in Eng.).

2.Цивільний кодекс України від 16 січня 2003 р. № 435-IV. Відомості Верховної Ради Украӥни. 2003. № № 40-44. Ст. 356.

3.Цивільне право : підручник : у 2-х кн. / за ред. О. Дзери, Н. Кузнєцової. Київ : Юрінком-Інтер, 2004. Кн. 1. 735 с.

4.Кравченко Т. Набуття права власності на майно за давністю володіння. iFactor. URL: https://i.factor.ua/ukr/journals/ms/2018/june/issue-6/1/article-37181.html.

5.Постанова Великої палати Верховного Суду у справі № 910/17274/17 від 14 травня 2019 p. / СДРСР. URL: http://www.reyestr.court.gov.ua/Review/82095858.

6.Печений О. Визнання права власності за набувальною давністю: підстави, порядок, процесуальні особливості. Вісник. 2019. № 4 (52). С.19-29.

7.Білий Я. Обставини, що мають бути доведені при вирішенні спорів, пов'язаних із набуттям права власності за набувальною давністю. URL: https://radako.com.ua/news/obstavini-shchomayut-buti-dovedeni-pri-virishenni-sporiv-povyazanih-iz-nabuttyam-prava.

8.Постанова Верховного Суду у складі колегії суддів Першої судової палати Касаційного цивільного суду від 1 серпня 2018 р. № 201/12550/16-ц / ЄДРСР. URL: http://www.reyestr.court. gov.ua/Review/75691639.

9.Постанова Верховного Суду у складі колегії суддів Касаційного господарського суду від 9 липня 2019 р. у справі № 920/999/16 / ЄДРСР. URL: http://www.reyestr.court.gov.ua/ Review/82937952.

10. Цивільне право України : навчальний посібник / кол. авторів ; за ред. Г. Яновицької, В. Кучера. Львів : Львівський державний університет внутрішніх справ, 2011. 468 с.

11. Цивільне право України : підручник : у 2-х т. Т. 1 / за заг. ред. В. Борисової, І. Спасибо-Фатєєвої. Київ : Юрінком-Інтер, 2007. 656 с.

12. Івашова І. Володіння як підстава виникнення права користування житлом. Правовий вісник Української академї̈ банківської справи. 2014. № 2 (11). С. 42-45.

13. Ухвала Верховного Суду у складі колегії суддів Касаційного господарського суду від 4 грудня 2018 р. у справі № 910/17274/17 / ЄДРСР. URL: http://www.reyestr.court.gov.ua/ Review/78296761. 